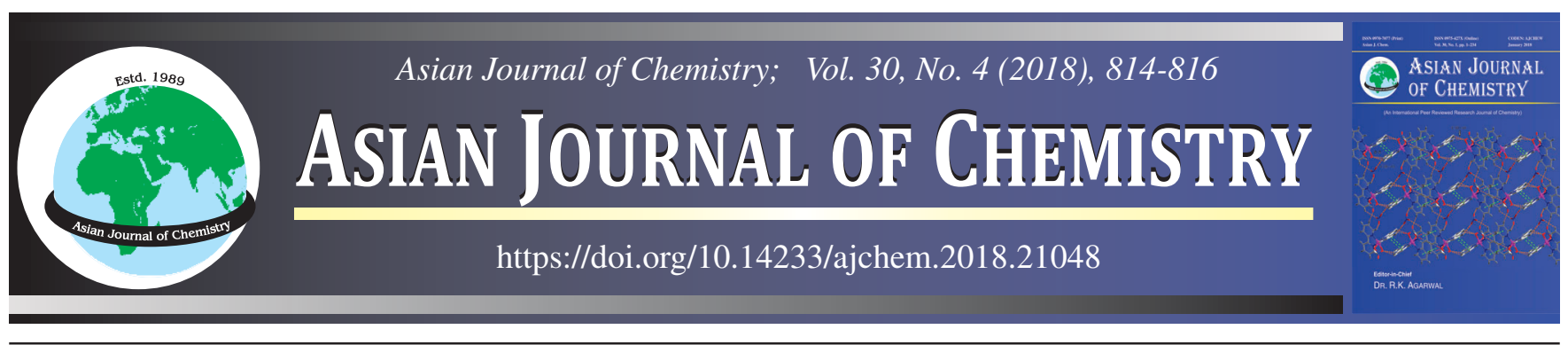

\title{
Isolation and Identification of Iridoid from Water Extract of Leaves of Vitex pinnata Linn. as Antioxidant
}

\section{Mastura $^{1,2, *}$, Tonel Barus ${ }^{2}$, Lamek Marpaung $^{2}$ and Partomuan Simanjuntak ${ }^{3}$}

${ }^{1}$ Samudra University, Meurandeh, Kota Langsa 24416, Aceh, Indonesia

${ }^{2}$ Sumatera Utara University, Medan, Indonesia

${ }^{3}$ Research Center for Biotechnology, Indonesian Institute of Sciences (LIPI), Jl. Raya Bogor Km. 46, Cibinong 16911, Indonesia

*Corresponding author: E-mail: mastura_fkipunsam@yahoo.co.id

An iridoid compound with antioxidant activity was isolated from the water extract of leaves of Halban (Vitex pinnata Linn.). Isolation and identification processes of the compound were performed based on the bioassay-activity-guided method using the free radical scavenging method for antioxidant. The purification was done by the column chromatography analysis $\left[\left(\mathrm{SiO}_{2}\right.\right.$; (i) dichloromethane:methanol = 5:1$1: 1$, (ii) dichloromethane:methanol:water $=5: 5: 1$, (iii) dichloromethane:methanol $=5: 1$ )] to give white powder. Chemical structure determination was done by an interpretation of spectroscopy data (UV, IR, NMR and MS) and revealed a glycoside iridoid compound with the high antioxidant activity $\left(\mathrm{IC}_{50} 27.3 \mathrm{ppm}\right)$.

Keywords: Vitex pinnata Linn., Glycoside iridoid, Antioxidant.

\section{INTRODUCTION}

Indonesia is rich with potential plants to be developed as drug materials. Research reported that more than 250 species of medicinal plants from 165 genus and 75 families have been used by Dayak Ransa tribe in West Kalimantan, Indonesia. Almost 200 species of wood plants have been used by Dayak Kenyah tribe in Apo Kayan plateau, Indonesia, as medicines [1]. Aceh province also has many potential plants for drug materials. One of them is Halban/Laban (Vitex pinnata Linn. Syn. Vitex pubescens Vahl.). Local people of Aceh province knew this plant as 'Oun Mane' and it is used as medicine for its anticholesterol, fever and stomach ache properties [2]. Burkill [3] also reported that the barks of this plant can relieve stomach ache, while its leaves can be used as medicine for fever and wounds. Fruits of $V$. pinnata contain a flavan-type flavonoid compound in the isomeric mixture [4].

Products from plants are rich with bioactive compounds that act as antioxidant to reduce excessive reactive oxygen species (ROS) produced by physiological process and many normal exogenic factors. Excessive ROS enhancement causes oxidative stress, leading to tissue damage by DNA, protein and lipid destruction [5]. The antioxidant in the body neutralizes free radicals. Therefore, foods rich in antioxidant are really needed by the body and the discovery of natural antioxidant from plant is continuously researched. Phenolic compound from plant is a secondary metabolite that has physiologic function in plant and it also has positive effects on human health since it can act as an antioxidant. An antioxidant plays an important role in preventing the pathogenic process related to cancer, cardiovascular disease, respiration disorders and immunity enhancement in the body [6,7]. The aims of this research are to isolate bioactive compounds in the leaves of $V$. pinnata Linn. and to find out their antioxidant activity.

\section{EXPERIMENTAL}

Samples were collected from Mananggini area, Kuala Simpang, Aceh province, Indonesia. Leaves were air dried under sunlight for 4 days to reach optimum dryness, which is followed by a grinding process to get fine powder.

Antioxidant activity test: The antioxidant activity test for samples was done by the free radical scavenging test modified by Molyneux [8] using $0.4 \mathrm{mM}$ DPPH (1,1-diphenylpicrylhydrazyl) as a reagent. The free radical scavenging activity by DPPH (inhibition) was calculated using the formulation:

$$
\text { Inhibition }(\%)=\frac{A_{o}-A_{1}}{A_{o}} \times 100
$$

where $A_{o}$ is the absorbance of blank and $A_{1}$ is the absorbance of sample. $\mathrm{IC}_{50}$ (inhibition concentration) is a value that shows antioxidant concentration $(\mu \mathrm{g} / \mathrm{mL})$ needed to inhibit $50 \%$ of 
free radicals. The $\mathrm{IC}_{50}$ value was obtained from interline between $50 \%$ of inhibition and concentration axes and then put in formula $\mathrm{Y}=\mathrm{a}+\mathrm{bx}$, where $\mathrm{Y}=50$ and $\mathrm{x}$ showed $\mathrm{IC}_{50}$ value. According to the National Cancer Institute, a compound or an extract is considered as having a good antioxidant activity if it has $\mathrm{IC}_{50}$ value $<20 \mu \mathrm{g} / \mathrm{mL}$ [9].

Extraction: Dry sample $(5 \mathrm{~kg})$ was macerated in methanol for $24 \mathrm{~h}$ and then filtered to separate filtrates from residue. The filtrate was evaporated using a rotary evaporator to get crude extract. This crude extract was dissolved in distilled water to get partitioned with ethyl acetate. Ethyl acetate and water phase were separated and evaporated to obtain dry extract to be followed with the antioxidant activity test.

Isolation and purification: Water extracts (32 g) were taken for the column chromatography analysis using $\mathrm{SiO}_{2}$ as a stationary phase and mixture of chloroform and methanol (5:1 1:1) and chloroform-methanol-water (5:5:1) as a mobile phase to give 4 fractions (VPWA-1-VPWA-4). Fraction VPWA4, which showed high antioxidant activity with $\mathrm{IC}_{50} 49.70 \mathrm{ppm}$ (Table-1), was purified further by column chromatography using $\mathrm{SiO}_{2}$ as a stationary phase and mixture of chloroform and methanol (5:1) as a mobile phase and gave 5 fractions (VPWA4.1-VPWA-4.5). Since fraction VPWA-4.4 showed the highest antioxidant activity ( $\mathrm{IC}_{50} 42.52 \mathrm{ppm}$ ), the purification process is then followed by the spectroscopy analysis (UV, IR, NMR and LC-MS).

\begin{tabular}{ccc}
\multicolumn{4}{c}{ TABLE-1 } \\
ANTIOXIDANT ACTIVITY OF EXTRACTS AND \\
\multicolumn{3}{c}{ FRACTIONS FROM LEAVES OF V. pinnata Linn. } \\
BY FREE RADICAL SCAVENGING METHOD \\
\hline No & Sample & IC $_{50}(\mathrm{ppm})$ \\
\hline 1 & $n$-Hexane ext & 152.80 \\
2 & Ethyl acetate extract & 24.75 \\
3 & Water extract & $\mathbf{3 1 . 7 2}$ \\
\hline 4 & VpWa-1 & 28.55 \\
5 & VpWa-2 & 113.46 \\
6 & VpWa-3 & 529.91 \\
7 & VpWa-4 & $\mathbf{4 9 . 7 0}$ \\
\hline 8 & VpWa-4-1 & 155.49 \\
9 & VpWa-4-2 & 95.494 \\
10 & VpWa-4-3 & 104.60 \\
11 & VpWa-4-4 & $\mathbf{4 2 . 5 2}$ \\
12 & VpWa-4-5 & 78.84 \\
13 & Vitamin C & 3.12 \\
\hline
\end{tabular}

\section{RESULTS AND DISCUSSION}

UV spectra gave maximum wavelength at $257.5 \mathrm{~nm}$ specific for aromatic ring and alkena chromophore. IR spectra showed wavelength at $3370 \mathrm{~cm}^{-1}$ (for hydroxyl), $1693 \mathrm{~cm}^{-1}(\mathrm{C}=\mathrm{O}), 1606$ $\mathrm{cm}^{-1}\left(\mathrm{C}=\mathrm{C}\right.$, aromatic) and $1120 \mathrm{~cm}^{-1}(\mathrm{C}-\mathrm{O})$.

${ }^{1} \mathrm{H}$ NMR spectra gave proton signals at high and low magnetic field areas (0-10 ppm), namely, high magnetic field showed protons substituted by oxygen at $\delta_{\mathrm{H}} 4.91$ and 5.09 $\left(=\mathrm{CH}_{2} \mathrm{O}_{-}\right)$and proton signals for sugar groups $\left(\delta_{\mathrm{H}} 3.25-4.70\right.$ $\mathrm{ppm})$. At a low magnetic field, it showed protons for aromatic ring compounds, alkena groups at $\delta_{\mathrm{H}} 5.1-7.91 \mathrm{ppm}$.

Based on ${ }^{13} \mathrm{C}$ NMR spectra and distortionless enhancement polarization transfer (DEPT), we revealed 22 carbon atoms with 16 doublets $(\mathrm{d})$ consisted by $7(\mathrm{CH}=), 7(\mathrm{CH}-\mathrm{O}-)$ and 2 $(-\mathrm{CH}-)$; 4 singlets $(\mathrm{s})[1(\mathrm{C}=\mathrm{O}-)$ and $3(-\mathrm{C}=)]$ and 2 triplet $(\mathrm{t})$ as $\left(-\mathrm{CH}_{2} \mathrm{O}-\right)[10,11]$.

The spectra analysis by total correlation spectroscopy (TOCSY) data shows the correlation between one proton and its adjacent protons that gave base for chemical structure determination of aucubin [12] and the presence of sugar groups [13] (Fig. 1).

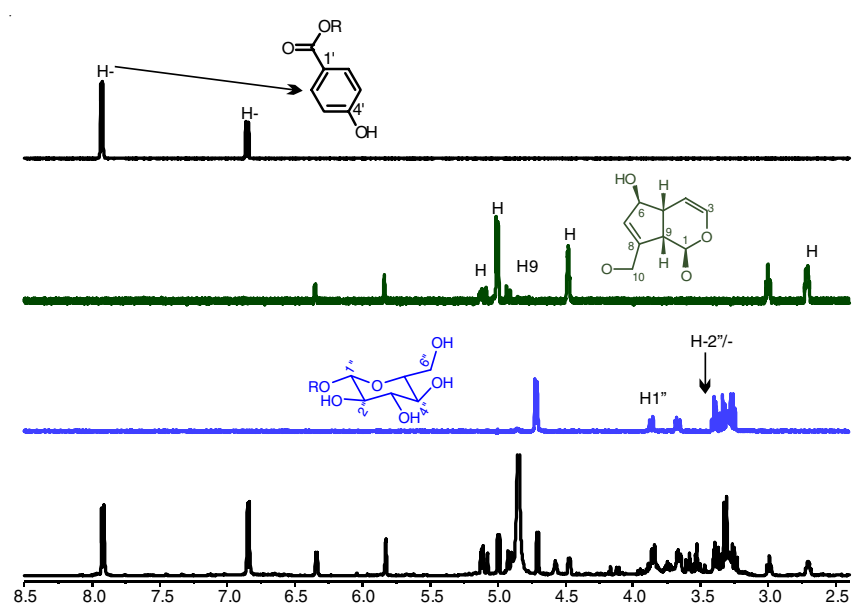

Fig. 1. TOCSY spectra for isolated compound VpWA-4.4

The spectral analysis by the homonuclear multibond connectivity (HMBC) experiment for isolated compound VpWA-4.4 showed correlation of $\mathrm{H}-1$ ( $\left.\delta_{\mathrm{H}} 4.99 \mathrm{ppm}\right)$ with carbon glycosidic $\left(\delta_{\mathrm{C}} 100.2 \mathrm{ppm}\right)$ and correlation of $\mathrm{H}-10\left(\delta_{\mathrm{H}} 4.91 \mathrm{ppm}\right.$ and $5.09 \mathrm{ppm})$ with carbonyl $\left(\delta_{\mathrm{C}} 167.8 \mathrm{ppm}\right)$ (Fig. 2).

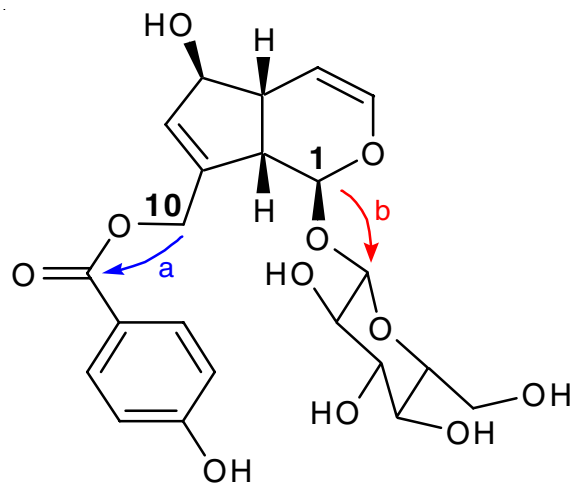

Fig. 2. HMBC Analysis for isolated compound VpWA-4.4

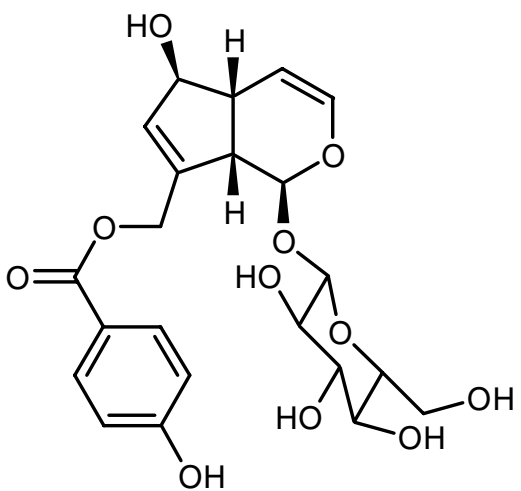

Fig. 3. Chemical structure of isolated compound from the leaves of Halban (V. pinnata) 


\begin{tabular}{|c|c|c|c|c|}
\hline \multicolumn{5}{|c|}{$\begin{array}{c}\text { TABLE-2 } \\
\text { COMPARISON OF }{ }^{1 \mathrm{H}} \text { NMR SPECTRA AND }{ }^{13} \mathrm{C} \text { NMR SPECTRA FC }\end{array}$} \\
\hline No. & $\begin{array}{l}{ }^{1} \mathrm{H} \text { NMR }\left(\delta_{\mathrm{H}}, \mathrm{ppm}, \mathrm{Hz}\right) \\
\text { Isolated comp. }(500 \mathrm{MHz})\end{array}$ & $\begin{array}{c}{ }^{1} \mathrm{H} \text { NMR }\left(\delta_{\mathrm{H}}, \mathrm{ppm}, \mathrm{Hz}\right) \\
\text { V. negundo [Ref. 14] }(400 \mathrm{MHz})\end{array}$ & $\begin{array}{l}{ }^{13} \mathrm{C} \mathrm{NMR} \\
\text { isolated comp. }\end{array}$ & $\begin{array}{l}{ }^{13} \text { C NMR V. negundo } \\
\text { [Ref. 14] }\end{array}$ \\
\hline 1 & $4.99,1 \mathrm{H}, d(7.5)$ & $6.28, d d$ & 97.9 & 98.0 \\
\hline 2 & - & - & - & - \\
\hline 3 & $6.34,1 \mathrm{H}, d d(2$ and 6.5$)$ & 2.7, $d d$ & 141.7 & 139.8 \\
\hline 4 & $5.1,1 \mathrm{H}, d d(4$ and 6$)$ & $5.10,4.6, d d$ & 105.5 & 105.6 \\
\hline 5 & $2.70,1 \mathrm{H}, m$ & $2.90, m$ & 46.3 & 46.4 \\
\hline 6 & $4.47,1 \mathrm{H}, m$ & $4.38, m$ & 82.8 & 82.9 \\
\hline 7 & $5.83,1 \mathrm{H}, t(2)$ & $5.80, s$ & 132.4 & 132.5 \\
\hline 8 & - & - & 142.9 & 140.2 \\
\hline 9 & $2.99,1 \mathrm{H}, t(7.6)$ & $2.90, m$ & 48.5 & 48.4 \\
\hline 10 & $4.91,1 \mathrm{H}, d(15) ; 5.09,1 \mathrm{H}, d(15)$ & $5.76, s$ & 63.6 & 63.7 \\
\hline 11 & - & - & - & - \\
\hline 12 & - & - & 167.8 & - \\
\hline $1^{\prime}$ & - & $4.69, d$ & 122.1 & 100.3 \\
\hline $2^{\prime}$ & $7.91,2 \mathrm{H}, d(8.8)$ & $3.65, m$ & 132.9 & 74.9 \\
\hline $3^{\prime}$ & $6.84,2 \mathrm{H}, d(8.8)$ & - & 116.2 & 78.0 \\
\hline $4^{\prime}$ & - & - & 163.6 & 71.5 \\
\hline $5^{\prime}$ & $6.84,2 \mathrm{H}, d(8.4)$ & - & 116.2 & 78.3 \\
\hline $6^{\prime}$ & $7.91,2 \mathrm{H}, d(8.8)$ & - & 132.9 & 62.8 \\
\hline $1 "$ & $4.70,1 \mathrm{H}, d(7.5)$ & - & 100.2 & 120.1 \\
\hline $2^{\prime \prime}$ & $3.25,1 \mathrm{H}, t$ & $7.86 \mathrm{dd}, 2.7 d d$ & 74.9 & 131.4 \\
\hline 3" & $3.40,1 \mathrm{H}, t$ & $7, d d$ & 77.9 & 115.3 \\
\hline $4 "$ & $3.30,1 \mathrm{H}, t$ & & 78.2 & 162.1 \\
\hline $5^{\prime \prime}$ & $3.34,1 \mathrm{H}, t$ & $7.27 d d$ & 71.4 & 115.3 \\
\hline 6" & $3.58,1 \mathrm{H}, d d(7.5) ; 3.85,1 \mathrm{H}, d d(7.5)$ & $6.86 d d$ & 62.4 & 131.4 \\
\hline
\end{tabular}

Based on the spectral data analysis, it is concluded that the compound in fraction VPWA-4.4 from water extract of V. pinnata is agnuside (Fig. 3). This compound also had been isolated from other genus of Vitex such as Vitex negundo [14] and Vitex trifolia [15]. A comparison of ${ }^{1} \mathrm{H}$ NMR spectra and ${ }^{13} \mathrm{C}$ NMR spectra for VPWA-4.4 and agnuside can be seen in Table-2.

Therefore, based on the UV, IR, NMR (1D and 2D) data interpretation and comparison of chemical shifts data $\left({ }^{1} \mathrm{H}\right.$ and ${ }^{13} \mathrm{C}$ NMR) from isolated compound of $V$. negundo from the reported data [14], it can be concluded that isolated compound of VpWA-4.4 from Vitex piñata is agnuside (Fig. 3).

\section{REFERENCES}

1. I.W. Kusuma, Murdiyanto, E.T. Arung, Syafrizal and Y. Kim, Food Sci. Human Wellness, 3, 191 (2014); https://doi.org/10.1016/j.fshw.2014.12.004.

2. Y. Ogata, Y. Kasahara and T. Iwasaki, Medicine Herb Index Indonesia, Eisai Indonesia, edn 2 (1995).

3. I.H. Burkill, A Dictionary of Economic Products of The Malay Peninsula, Ministry of Agriculture and Cooperative, Kuala Lumpur, Vol. II (1966).

4. Syafruddin, Isolasi dan Identifikasi Senyawa Flavonoid dari Buah Laban (Vitex pinnata Linn.) Asal Nanggroe Aceh Darussalam, Serambi Saintia: Vol. 1, No. 1 (2013) (In Indonesian).
5. L.A. del Río, J. Exp. Bot., 66, 2827 (2015); https://doi.org/10.1093/jxb/erv099.

6. S. Mahmoudi, M. Khali, A. Benkhaled, K. Benamirouche and I. Baiti, Asian Pac. J. Trop. Biomed., 6, 239 (2016); https://doi.org/10.1016/j.apjtb.2015.12.010.

7. S. Mondal, R.R. Phadke and A.M. Badigannavar, Euphytica, 204, 311 (2015); https://doi.org/10.1007/s10681-014-1324-9.

8. P. Molyneux, Songklanakarin J. Sci. Technol., 26, 211 (2004).

9. M.R. Boyd, ed. B.A. Teicher, The NCI in vitro Anticancer Drug Discovery Screen: Concept, Implementation and Operation (1985-1995), In: Anticancer Drug Development Guide, Preclinical Screening, Clinical Trials and Approval, Humana Press, Totowa, pp. 23-42 (1997).

10. E. Pretsch, P. Bühlmann and C. Affolter, Structure Determination of Organic Compounds, Springer-Verlag Berlin Heidelberg (2009).

11. R.M. Silverstein, G.C. Basler and T.C. Morrill, Spectroscopic Identification of Organic Compounds, John Wiley \& Sons Publ. (1986).

12. L.J. El-Naggar and J.L. Beal, J. Nat. Prod., 43, 649 (1980); https://doi.org/10.1021/np50012a001.

13. M. Reichenbächer and J. Popp, Challenges in Molecular Structure Determination, Springer-Verlag, Berlin Heidelberg (2012).

14. S. Roy, K. Bairwa, J. Grover, A. Srivastava and S.M. Jachak, J. Anal. Chem., 70, 639 (2015); https://doi.org/10.1134/S1061934815050147.

15. S. Shah, T. Dhanani and S. Kumar, J. Pharm. Anal., 3, 500 (2013); https://doi.org/10.1016/j.jpha.2013.09.008. 